\title{
Quantile nexus between human development, energy production, and economic growth: the role of corruption in the case of Pakistan
}

\author{
Muhammad Luqman $^{1} \cdot$ Yafei Li $^{2}$ (D) $\cdot$ Salah Ud-Din Khan ${ }^{3} \cdot$ Najid Ahmad $^{4}$ \\ Received: 23 December 2020 / Accepted: 1 June 2021 / Published online: 26 June 2021 \\ (C) The Author(s), under exclusive licence to Springer-Verlag GmbH Germany, part of Springer Nature 2021
}

\begin{abstract}
This paper examines the quantile cointegration relation between human development, energy production, and economic growth by incorporating corruption into the model for Pakistan through Quantile Autoregressive Distributed Lag (QARDL) model covering the period from 1965 to 2016. The research findings indicate that the association is quantile dependent which provides some exciting results. The Wald test is applied that rejects the null hypothesis and confirms the short- and long-run relationship between the variables. The changes in human development and economic growth are responsible for past and current changes in energy production and corruption that is confirmed through the Error Correction Model (ECM). This paper provides some interesting findings that energy production is contributing positively to human development. Further, energy production contributes negatively to economic growth, while corruption contributes positively to economic growth. These findings will help to make policy measures such as environmental regulation to improve energy efficiency and anti-corruption policies which will improve income level and economic growth of Pakistan economy.
\end{abstract}

Keywords Human development · Energy production · Corruption · Economic growth · Quantile Autoregressive Distributed Lag model

\section{Introduction}

Human development and energy production are a growing concern for countries that are facing economic and sustainable development problems. Limited research has been carried out to understand the considerable impacts on sustainable development and its economic consequences. It is relatively a complex phenomenon to study how human actions could affect the process of energy, corruption, and economic growth. Therefore, to study such a complex phenomenon from the

Responsible editor: Ilhan Ozturk

Yafei Li

ouyang946453@163.com

1 School of Economics, Qingdao University, Qingdao, People's Republic of China

2 School of Economics, Peking University, Beijing, China

3 Sustainable Energy Technologies Center, College of Engineering, King Saud University, Riyadh, Saudi Arabia

4 School of Business, Hunan University of Science and Technology, Xiangtan, Hunan, China growth and policy perspectives, it is better to start with some real facts. According to Karekezi et al. (2012), energy is a significant element to culminate hunger and poverty to sustain human and economic development. It is also seen that energy is considered as a backbone of the economy to achieve the country's millennium development goals (MDs). This paper extended this debate by including the importance of human development, which has a pedigree in policymaking organizations like the World Bank and IMF. Therefore, in this era of globalization, energy production, human development, and corruption had the primary concerns of the policymakers and considered an essential element in the process of development.

In literature, most of the researchers apply different econometric techniques for different countries. However, beyond the importance of corruption to economic growth, the association between energy and growth is also a growing concern due to the facts of global warming, as energy is playing a crucial role in the growth process in this era of industrialization and globalization (Warr and Ayres 2010). The relationship between energy and growth has been broadly explored (Aslan et al. 2014; Chiou-Wei et al. 2008; Dogan et al. 2016; Kahsai et al. 2012; Ozturk et al. 2010). Besides the impacts of 
corruption and energy on growth, energy is also affecting human development. There exists a straight association between energy facilities and current well-being of the people. The weak energy system indicates an inadequate health system, limited education facilities, and poor development structure (Ouedraogo 2013a). However, energy production is an essential element that indicates the level of human development in any country. In this era of globalization, it is a need to produce more energy to achieve an advanced sustainable development level (Niu et al. 2013). Beyond the importance of energy and human development to economic growth, the role of corruption cannot be ignored to study the association between these selected variables. However, from the literature, it is seen that corruption lowers the growth process that hampers the public and private sectors, which in turn inhabitants the efficiencies in the public sector. Some scholars find a positive association between corruption and economic growth (see Gani 2021; (Mauro 1995; Helene Poirson Ward 1998; RoseAckerman 1999a; Mo 2001; Del Monte and Papagni 2001; Gyimah-Brempong 2002; Svensson 2005; GyimahBrempong and de Gyimah-Brempong 2006; Taiwo and Elumilade 2007; Tsaturyan and Bryson 2009; Ishola Mobolaji and Omoteso 2009; Maiyaki 2010; Johnson et al. 2011; d'Agostino et al. 2012; Dridi 2013; Shera et al. 2014), while some researchers argue that corruption is negatively contributing to economic growth (see Acemoglu and Verdier 1998; Ahmad et al. 2012; Bayley 1966; Huntington 1970; Klitgaard 1988; Leff 1964; Lui 1985; Paksha 2010; Swaleheen 2011; Wedeman 1997). However, few studies show the direct effect of corruption on energy policies (Fredriksson et al. 2004; Gani 2021). Therefore, the role of corruption with energy production, human development, and economic growth cannot be ignored. Knowing the importance of energy, human development, and corruption motivates us to quantify how these factors could influence the process of human development, energy production, and economic growth in Pakistan. Therefore, the innovation of this paper is to not only quantify the relationship between human development, energy production, corruption, and economic growth but also introduce some policy measures for the Pakistan economy.

As the case of Pakistan, there are some fascinating facts that make this study very interesting. According to UNDP (2018) report, the human development of Pakistan is very complicated and vulnerable, which ranks the country on 146th among 186 countries in the world according to the Human Development Index (HDI). Further, 49\% population of the country is under multiple deprivations, and $11 \%$ is in an unsafe condition. Similarly, the Gender Inequality Index is also vulnerable $(0.55)$ and ranks the country at the 123 rd level in 146 countries (Fig. 1). The main reason for the lower level of human development is due to the inadequate education system and rising or stagnant over the past 5 years (Wang et al. 2018). Another fact for Pakistan's economy is that it is facing energy crises and a war against terrorism. The country is bearing much expenditure to deal with these issues that not only affect the economic growth but create a burden of terrorism-affected people (like, refugees, and the disabled population). It also creates a significant burden on the Pakistan economy (Shahbaz et al. 2012). In the case of energy, the country is ranked among the top ten countries that have an enormous impact on climate change in the world. The cost of adaptation for climate change mitigation is around $\$ 10$ billion per year (UNDP 2014). The recent scenario of energy production in the country is also a risk that is creating energy crises, which are affecting each sector of the economy and people's subjective well-being severely. At last, the Corruption Perception Index (CPI) of the country is also in a worse situation. The CPI ranks the countries between 0 to 100 ( 0 indicates the most corrupt, and 100 indicates the cleanest country). In the case of Pakistan, CPI ranks the country at the 32nd position that is in the deficient category in the whole world (Fig. 2). These facts offer some footprints for the future of the country if some proper measures are not taken on time by the Pakistani government and policymakers. However, the results of this study provide initiative policy measures for the country that may help to improve the situation of human development and energy production and control corruption in the country.

This work contributes to the literature in many ways: first, to our best knowledge, this study is a new attempt that not only quantifies the linkage between human development, energy production, corruption, and economic growth but also provides effective policy measures. Second, limited literature such as Vasylieva et al. (2019), Wang et al. (2018), Costantini and Monni (2008), Ray et al. (2016), and Fang and Chang (2016) quantified the association between renewable energy consumption, energy consumption, and human development to economic growth but did not address the role of energy production and corruption to human development and economic growth. Therefore, this paper fills this research gap by including energy production and corruption into the model. Third, a new econometric model by Cho et al. (2015) for the Quantile Autoregressive Distributed Lag (QARDL) is used in the present study. To our best knowledge, the linearity and asymmetric association has not to be checked by using the QARDL model in the literature. Therefore, the finding of this paper provides real insights for policymakers and government bodies to understand the association between these economic variables.

The rest of the paper is organized as follows: the "Conceptual background" section highlights the conceptual background on human development, energy, corruption, and economic growth. The econometric model, variable explanation, and data sources are explained in the "Model, method, data" section, while in the "Results and discussion" section, the detailed results with policy perspectives are explained with 
Fig. 1 Human Development Index (HDI). Note: Authors own calculations based on the data that is extracted from UNDP (2018)

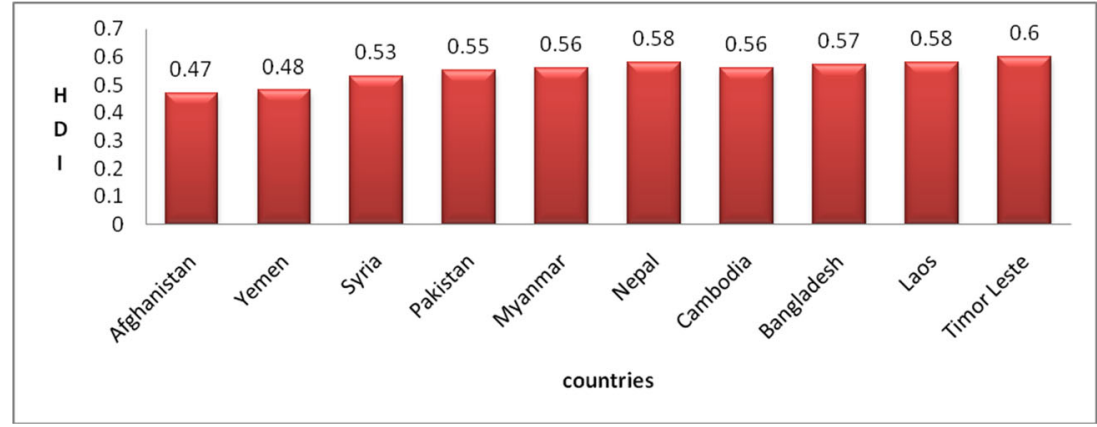

economic reasoning. The "Conclusion and policy suggestion" section concludes this work and draws important policy measures.

\section{Conceptual background}

In this section, the nexus between human development, energy, corruption, and economic growth has been explored. Three streams are studied to highlight the impacts and policy importance between the selected variables. In the first stream, the impacts and policy importance of energy and economic growth are studied, while in the second stream, the impacts and policy importance of human development and economic growth are studied. Finally, in the third stream, the impacts and importance of corruption and economic growth are studied.

\section{Energy-economic growth}

Various scholars' thoughts are studies of the association between energy and economic growth. Few scholars supported the long-run association between energy consumption and economic growth. In this line, Ouedraogo (2013a) investigated the causal relationship between energy consumption and economic growth for the West African States and found a long-run causality coming from economic growth (GDP) to energy consumption. Dogan (2014) examined the causal relationship between economic growth for Kenya, Benin, and Zimbabwe in the period of 1971-2011 and found mixed results for each country. Nasreen and Anwar (2014) found a bi-directional causal relationship between energy and economic growth for 15 countries in the period of 1980-2011. Acaravci et al. (2015) examined the relationship between electricity consumption and economic growth for Turkey during the period of 1974-2013, and a unidirectional causal relationship was found, which was coming from electricity consumption to economic growth. Dogan (2015) found a causal relationship between natural gas consumption and economic growth for Turkey in the period of 1995-2012 and supported the feedback hypothesis. Dogan et al. (2016) examined the relationship between agricultural electricity consumption and the output of non-coastal areas and found a bi-directional causal relationship between the entire variables for Turkey from 1995 to 2013. Fang and Chang 2016 examined the causal relationship between growth and energy for the Asia Pacific from 1970 to 2011. Furuoka (2016) investigated a unidirectional causal relationship between natural gas consumption and economic growth for China and supported the feedback hypothesis for Japan from 1980 to 2012. Menegaki and Tugcu (2016) found the neutrality hypothesis between GDP and energy use for 42 sub-Saharan.

Few scholars supported the association between energy production and economic growth. Limited literature has been found on energy production and economic growth. In the debate on energy production, much attention is paid to
Fig. 2 Corruption Perception Index (CPI). Note: Authors own calculations based on the data that is extracted from "Corruption Perception Index" (2021)

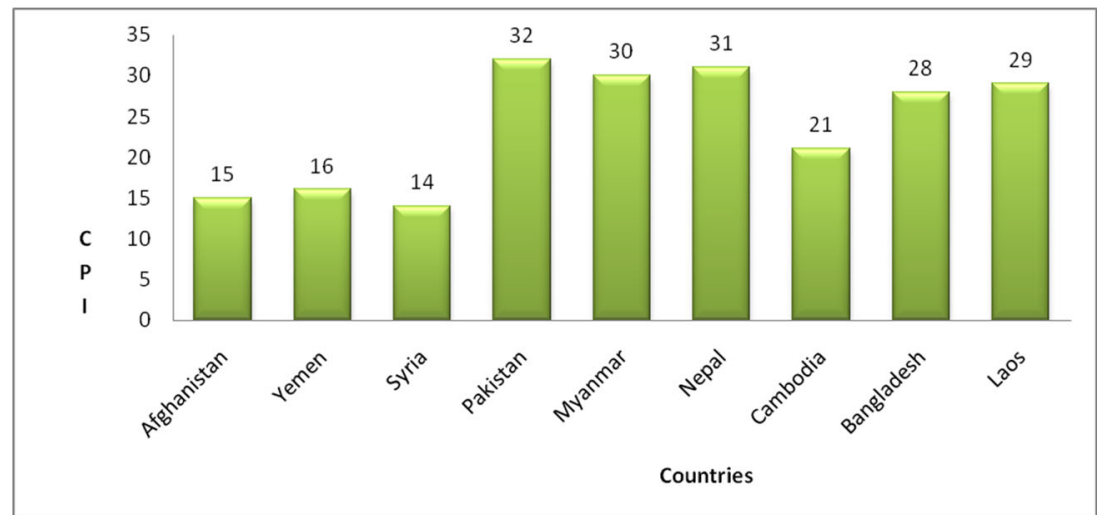


energy production and economic growth. In this line, this paper widens this debate by examining the relationship between energy production and economic growth due to the study objective. Ahmad and Du (2017) applied the ARDL and Granger causality models to explore the causal relationship between energy production $\mathrm{CO}_{2}$ emission and economic growth for Iran by covering the period of 1971-2011 and found a positive association between energy production, $\mathrm{CO}_{2}$ emission, and economic growth. Khan et al. (2019) examined that coal, oil, and natural gas consumption and economic growth have a positive effect on environmental degradation in Pakistan that can improved by introducing renewable energy sources. Ozcan et al. (2020) found that energy consumption and economic growth enhance countries environmental performance that depends on environmental policies in OECD.

\section{Human development-economic growth}

This stream of literature examined the relationship between human development and economic growth. The paper of Suri et al. (2011) found a bi-directional causal relationship between human capital and economic development through an econometric model. Following this line of reasoning, there are fewer analyses or discussions on whether the scarcity of human capital is critical in sustaining such traps. Ouattara (2004) argues in favor of all kinds of human development, an argument in tandem with the work of Blume and Voigt (2007), who found a positive relationship in the interaction of human and economic development. Another scrutiny of human capital by including trade openness studied by Mustafa et al. (2017) for Asian countries and include governance and law to scrutinize the relationship among the variables. While the paper of Rogers (2008) found that country-specific characteristics such as "corruption, black market premium, and brain drain" will be made human capital in unproductive manners. While Schündeln and Playforth (2014) found that social return is enhancing human capital. Ahsan and Haque (2017) used a proxy of years of schooling for human capital and found a threshold level for human capital with growth and argued that human capital cannot assert its production role for growth even when the economy crossed a certain threshold level. The relationship between human development and economic growth found mixed results. Khodabakhshi (2011) examined the merger effect on human development with economic growth for India. Similarly, Costantini and Monni (2008) investigated the association between growth, sustainability, and human development for 179 countries and suggested that the underlying agenda of development can be achieved by improving living standards in the developing countries that will accumulate the human capital. It means that the human development process was essential for sustainable development for any country. Hafner and Mayer-Foulkes (2013) initiated NIL association in human development and income in the panel of 72 countries. A compelling argument on energy and human development for economic growth was introduced by Fang and Chang (2016) for Asian countries and found a cointegration relationship between the variables, but results varied from country to country. Wang et al. (2018) found that renewable energy was not cultivating in the progress of the human development of Pakistan. Mohmmed et al. (2019) found a strong association between Human Development Index, growth, and healthy life expectancy along with sector $\mathrm{CO} 2$ emission for top ten emitters' countries. Ferrannini et al. (2021) introduced a new framework on industrial policy for sustainable human development to identify industrial policy governance for the post COVID-19 era. Thus, using the previous point of view, we conclude that policymakers must not only view the outcomes of economic growth but also take into account those essential preconditions to achieving a higher growth rate.

\section{Corruption-economic growth}

The association between corruption and economic growth is also a growing concern of the economists of the era. Numerous studies found that corruption hurts economic growth. In this line, Mauro (1995) examined cross-country and found that corruption was affecting investment and growth processes severely. Helene (1998) found a negative association between corruption and economic growth. RoseAckerman (1999b) found that corruption was not only negatively affecting financial investment, economic growth, and government expenditure but creating an imbalance in expenditure, misguiding the market, and poorly allocation in national resources, while Mo (2001) argued that corruption was affecting economic growth negatively after incorporating the variables like political instability, human capital, and investment. Similarly, Del Monte and Papagni (2001) found corruption not only limited the average labor income level but also affected the investment level that in return affected the growth and public investment in Italy. Gyimah-Brempong (2002) found that corruption was affecting growth and income level in African countries. Svensson (2005) followed the argument of Mauro (1995), who argued that corruption was affecting economic growth negatively. GyimahBrempong and de Gyimah-Brempong (2006) found that corruption had a different impact on economic growth in different stages of economic development over 20 years in the panel of African, OECD, and Asian countries. Taiwo and Elumilade (2007) found a negative causal association between corruption and economic growth for Nigeria. Ishola Mobolaji and Omoteso (2009) supported Mauro's argument that corruption affects growth negatively. Tsaturyan and Bryson (2009) found a negative association between corruption and economic growth in the panel of 39 countries. Maiyaki (2010) argued that corruption slowed the growth, which led to inefficiency in 
investment in the public projects that hinder foreign investment. Johnson et al. (2011) found that corruption has a negative causality with investment and growth in the USA. Dridi (2013) argued that corruption hurt economic growth that in turn affects human capital and political instability. Similarly, Shera et al. (2014) also found a negative association between corruption and economic growth on panel data analysis. Similarly, corruption can also influence human development and economic development. According to Shi and Pan (2018), social tolerance on corruption could affect economic development through a dynamic-interaction model.

Few studies found that corruption has a positive impact on economic growth. They believed that corruption could heighten the administrative efficiency of government bodies and decrease the transaction of time that impacts positively on economic growth. Leff (1964), Bayley (1966), and Huntington (1970) argued that with certain circumstances, individuals can bribe policymakers in the case of unfavorable situations due to political instability and law and regulation that cause economic efficiency, while Klitgaard (1988) and Acemoglu and Verdier (1998) found that there existed an optimal level of corruption in case of pursuing high output. Wedeman (1997) argued that the countries with higher growth level generally have higher corruption. Similarly, Paksha (2010) found a positive association between corruption and economic growth for Bangladesh. Swaleheen (2011) examined a significant positive impact of corruption on growth, while Ahmad et al. (2012) found a decreasing trend in corruption has an increasing trend in economic growth that is in an inverted U-shaped. Similarly, recent literature showed that the impact of corruption on economic growth is due to autocracy which transmits the growth to decrease FDI and increase inflation (Gründler and Potrafke 2019). Qureshi et al. (2021) found that corruption control can affect inward FDI and growth in developing and developed economies. Song et al. (2021) found a positive effect of financial development to economic growth, while corruption has a negative effect.

Summarizing, these studies indicate that these variations play an important role in energy production and economic growth. Therefore, we include human development and corruption to account their effects on energy and growth in our model.

\section{Model, method, data}

\section{Model specification and method}

To examine the relationship between human development, energy production, and economic growth by adding corruption into the single framework, we develop the model as follows:

$H_{t}=\alpha_{0}+\beta_{1} Y_{t}+\beta_{2} E_{t}+\beta_{3} C_{t}+\mu_{1}$
Avoiding the dynamic properties that are associated with data, we have taken the logarithmic form of the data. Therefore, the logarithmic form of Eq. (1) can be written as follows:

$$
\begin{aligned}
\log \left(H_{t}\right)= & \alpha_{0}+\beta_{1}\left[\log \left(Y_{t}\right)\right]+\beta_{2}\left[\log \left(E_{t}\right)\right]+\beta_{3}\left[\log \left(C_{t}\right)\right] \\
& +\mu_{1}
\end{aligned}
$$

where $\mathrm{H}$ denotes for Human Development Index, $\mathrm{Y}$ denotes for economic growth, E denotes for energy production, $\mathrm{C}$ denotes for Corruption Perception Index, and $\mu$ denotes for stochastic error term.

This paper applies the newly developed QARDL model of Cho et al. (2015) to investigate the relationship between the variables for Pakistan. Technically, the QARDL model has three advantages compared to linear models. First, this model allows for the asymmetric locations in which the parameter depends on the locations of the dependent variable with their conditional distributions. Second, the QARDL model simultaneously reports a long-run association between the variables across the whole range of quantiles along with short-run dynamics with the conditional distributions of crude oil and gold. Third, except for this paper, few scholars found the lack of cointegration in time series by applying outdated econometric techniques, like Johansen's cointegration test and the ARDL model. Therefore, this adverse outcome can be overcome by examining the existence of quantile cointegration coefficients for the short- and long-term periods (Xiao 2009). Another advantage of the QARDL model is that it allows for cointegrating coefficients which vary due to shocks. This model is also superior to other nonlinear econometric models, like the Nonlinear Autoregressive Distributed Lag (NARDL) model (Shin et al. 2014). These possible reasons make the QARDL model an appropriate and accurate model, which covers both the nonlinear and the asymmetric links in energy and metal markets. This method allows testing quantile long-run equilibrium effects of human development, corruption, and economic growth on energy production. The Wald test is applied to check the cointegration relation across the cointegrating coefficients in all quantiles. The Autoregressive Distributed Lag (ARDL) model can be written in the following form:

$H_{t}=\alpha+\sum_{i=1}^{p} \varphi_{i} H_{t-i}+\sum_{i=0}^{q_{1}} \omega_{i} Y_{t-i}+\sum_{i=0}^{q_{2}} \lambda_{i} E_{t-i}+\sum_{i=0}^{q_{3}} \theta_{i} C_{t-i}+\varepsilon_{t}$

where $\varepsilon_{t}$ denotes for error term that is measured as $H_{t}-E$ $\left({ }^{H} / F_{t-1}\right)$ in which $F_{t-1}$ is the smallest $\sigma$-fieldthat is computed as $\left\{E_{t}, Y_{t}, C_{t}, H_{t-1}, E_{t-1}, Y_{t-1}, C_{t-1}, \ldots \ldots \ldots \ldots\right\}$, and $p$, $q_{1}, q_{2}$, and $q_{3}$ are lags order that is chosen through the Schwarz Information Criterion (SIC). In Eq. (3), $H_{t}, Y_{t}, \mathrm{C}_{t}$, and $\mathrm{E}_{t}$ express the logarithmic form of human development, economic growth, corruption, and energy production, respectively. 
The ARDL model is extended by Cho et al. (2015) into the QARDL model. Therefore, the primary form of the QARDL model is written as follows:

$$
\begin{aligned}
& Q_{H_{t}}=\alpha(\tau)+\sum_{i=1}^{p} \varphi_{i}(\tau) H_{t-i}+\sum_{i=0}^{q_{1}} \omega_{i}(\tau) Y_{t-i}+\sum_{i=0}^{q_{2}} \lambda_{i}(\tau) E_{t-i} \\
& +\sum_{i=0}^{q_{3}} \theta_{i}(\tau) C_{t-i}+\varepsilon_{t}(\tau)
\end{aligned}
$$

where $\varepsilon_{t}(\tau)=H_{t}-Q_{H_{t}}\left(\tau / F_{t-1}\right)$, while $Q_{H_{t}}\left(\tau / F_{t-1}\right)$ is representing the $\tau$-th $\tau$ - thquantile of $H_{t}$ on the given condition of the information set defined above.

We reformulate Eq. (4) to represent the modified form of QARDL model as follows:

$Q_{H_{t}}=\alpha(\tau)+\sum_{i=1}^{q_{1}-1} \delta_{Y i}(\tau) \Delta Y_{t-1}+\gamma_{Y}(\tau) Y_{t}+\sum_{i=1}^{q_{2}-1} \delta_{E i}(\tau) \Delta E_{t-1}+\gamma_{E}(\tau) E_{t}$

$+\sum_{i=1}^{q_{3}-1} \delta_{C i}(\tau) \Delta C_{t-1}+\gamma_{C}(\tau) C_{t}+\varepsilon_{t}(\tau)$

where

$$
\begin{aligned}
\gamma_{Y}(\tau) Y_{t} & =\sum_{i=0}^{q_{1}} \omega_{i}(\tau), \delta_{Y_{t}}(\tau)=-\sum_{j=i+1}^{q_{1}} \omega_{i}(\tau), \gamma_{E}(\tau) E_{t} \\
& =\sum_{i=0}^{q_{1}} \lambda_{i}(\tau), \\
\delta_{E_{t}}(\tau) & =-\sum_{j=i+1}^{q_{1}} \lambda_{i}(\tau), \gamma_{C}(\tau) C_{t}=\sum_{i=0}^{q_{1}} \theta_{i}(\tau), \text { and } \delta_{C_{t}}(\tau) \\
& =-\sum_{j=i+1}^{q_{1}} \theta_{i}(\tau) .
\end{aligned}
$$

Equation (5) only captures the short-run dynamics. The long-run relationship between energy production, corruption, economic growth, and human development is captured by modifying Eq. (5) as follows:

$Q_{H_{t}}=\mu(\tau)+X_{t}^{\prime} \beta(\tau)+M_{t}(\tau)$

where in Eq. (6), $X_{t}^{\prime}$ is a $k \times 1$ vector of integrated regressors with order one, but the $\mathrm{k}$ variables are not cointegrated among themselves. $\mathrm{X}$ denotes for energy production, economic growth, and corruption. While $\beta_{Y}(\tau)=\gamma_{Y}(\tau)\left[1-\sum_{i=1}^{p} \varphi_{Y_{i}}(\tau)\right], \beta_{E}(\tau)$ $=\gamma_{E}(\tau)\left[1-\sum_{i=1}^{p} \varphi_{E_{i}}(\tau)\right], \beta_{C}(\tau)=\gamma_{C}(\tau)\left[1-\sum_{i=1}^{p} \varphi_{C_{i}}(\tau)\right]$ and $\quad M_{t}(\tau)=\sum_{j=0}^{\infty} \partial_{Y_{J}}(\tau) \Delta Y_{t-1}+\sum_{j=0}^{\infty} \theta_{Y_{J}}(\tau) \Delta \varepsilon_{t-1}$, with $\mu(\tau)=\alpha(\tau)\left[1-\sum_{i=1}^{p} \varphi_{i}(\tau)\right]^{-1}$, and $\partial_{j}(\tau)=\sum_{l=j+1}^{\infty} \pi_{l}(\tau)$. where $\left\{\theta_{0}(\tau), \theta_{1}(\tau), \ldots \ldots \ldots \ldots\right\}$ and $\left\{\pi_{0}(\tau), \pi_{1}(\tau), \ldots \ldots \ldots\right\}$ are defined as $\quad \sum_{i=0}^{\infty} \theta_{i}(\tau) L^{i}=\left(1-\sum_{i=1}^{p} \varphi_{i}(\tau) L^{i}\right)^{-1} \quad$ and $\sum_{i=0}^{\infty} \pi_{i}(\tau) L^{i}=(1-L)^{-1}\left(\begin{array}{cc}\sum_{1} \sum_{i=}(\tau) L^{i} & q_{1} \\ \frac{\sum_{i=0}(\tau)}{q_{1}} & -\frac{\sum_{i=1}(\tau) L^{i}}{q_{1}} \\ 1-\sum_{i=1}(\tau)\end{array}\right)$.

We simplify our model to avoid the problem of serial correlation as follows:

$$
\begin{aligned}
& Q_{\Delta H_{t}}=\alpha+\rho H_{t-1}+\varphi_{Y} Y_{t-1}+\varphi_{E} E_{t-1}+\varphi_{C} C_{t-1}+\sum_{i=1}^{p} \varphi_{i}(\tau) \Delta H_{t-1} \\
& +\sum_{i=0}^{q_{1}} \omega_{i}(\tau) \Delta Y_{t-1}+\sum_{i=0}^{q_{2}} \lambda_{i}(\tau) \Delta E_{t-1}+\sum_{i=0}^{q_{3}} \theta_{i}(\tau) \Delta C_{t-1}+v_{t}(\tau)
\end{aligned}
$$

Applying the model that is presented in Eq. (7) introduces a correlation between $v_{t}$ and $\Delta Y_{t}, \Delta E_{t}$, and $\Delta C_{t}$. By applying the projection of $v_{t}$ on $\Delta Y_{t}, \Delta E_{t}$, and $\Delta C_{t}$ in the form of $v_{t}=\gamma_{Y} \Delta Y_{t}+\gamma_{E} \Delta E_{t}+\gamma_{C} \Delta C_{t}+\varepsilon_{t}$. Now $\varepsilon_{t}$ is uncorrelated with $\Delta Y_{t}, \Delta E_{t}$, and $\Delta C_{t}$. We incorporate these previous projections into Eq. (7) and generalize the quantile framework that leads to the QARDL-ECM model (Model 1) as follows:

$$
\begin{aligned}
\Delta Q_{H_{t}} & =\alpha(\tau)+\rho(\tau)\left(H_{t-1}-\beta(\tau) Y_{t-1}-\beta(\tau) E_{t-1}-\beta(\tau) C_{t-1}\right) \\
& +\sum_{i=1}^{p-1} \varphi_{i}(\tau) \Delta H_{t-1}+\sum_{i=0}^{q_{1}-1} \omega_{i}(\tau) \Delta Y_{t-1}+\sum_{i=0}^{q_{2}-1} \lambda_{i}(\tau) \Delta E_{t-1} \\
& +\sum_{i=0}^{q_{3}-1} \theta_{i}(\tau) \Delta C_{t-1}+\varepsilon_{t}(\tau)
\end{aligned}
$$

Similarly, when we take energy production and economic growth (Model 2 and Model 3) as the dependent variable, the QARDL-ECM model is written as follows:

$$
\begin{aligned}
& \Delta Q_{E_{t}}=\alpha(\tau)+\rho(\tau)\left(E_{t-1}-\beta(\tau) Y_{t-1}-\beta(\tau) H_{t-1}-\beta(\tau) C_{t-1}\right) \\
& +\sum_{i=1}^{p-1} \varphi_{i}(\tau) \Delta E_{t-1}+\sum_{i=0}^{q_{1}-1} \omega_{i}(\tau) \Delta Y_{t-1}+\sum_{i=0}^{q_{2}-1} \lambda_{i}(\tau) \Delta H_{t-1} \\
& +\sum_{i=0}^{q_{3}-1} \theta_{i}(\tau) \Delta C_{t-1}+\varepsilon_{t}(\tau)
\end{aligned}
$$

$$
\begin{aligned}
& \Delta Q_{Y_{t}}=\alpha(\tau)+\rho(\tau)\left(Y_{t-1}-\beta(\tau) E_{t-1}-\beta(\tau) H_{t-1}-\beta(\tau) C_{t-1}\right) \\
& +\sum_{i=1}^{p-1} \varphi_{i}(\tau) \Delta Y_{t-1}+\sum_{i=0}^{q_{1}-1} \omega_{i}(\tau) \Delta E_{t-1}+\sum_{i=0}^{q_{2}-1} \lambda_{i}(\tau) \Delta H_{t-1} \\
& +\sum_{i=0}^{q_{3}-1} \theta_{i}(\tau) \Delta C_{t-1}+\varepsilon_{t}(\tau)
\end{aligned}
$$

The cumulative short-term impacts of past human development on current human development are measured as $\varphi_{*}=\sum_{j=1}^{p-1} \varphi_{j}$. Similarly, the cumulative short-term impacts of energy consumption and economic growth are measured, while the cumulative short-term impacts of current and previous levels of economic growth, energy production, and corruption are 
measured as $\omega_{*}=\sum_{j=1}^{q_{1}-1} \omega_{j}$ and $\lambda_{*}=\sum_{j=1}^{q_{2}-1} \lambda_{j}$ and $\theta_{*}=\sum_{j=1}^{q_{3}-1} \theta_{j}$.

Similarly, the cumulative short-term impacts of current and previous levels of human development, economic growth, and corruption are measured by following the above method. The longrun cointegration parameters of economic growth, energy production, and corruption are calculated as $\beta_{Y}=-\frac{\varphi_{Y}}{\rho}, \beta_{E}=-\frac{\varphi_{E}}{\rho}$ and $\beta_{C}=-\frac{\varphi_{C}}{\rho}$, respectively. The cumulative short- and long-run cointegration parameters are measured through the delta method.

This paper applies the Wald test statistics to investigate the short- and long-run nonlinear and asymmetric impacts of economic growth, energy production, and corruption on human development (Model 1). It is worth noting that the Wald test follows a chi-square distribution that tests the null and alternative hypothesis of short- and long-run parameters, $\varphi_{*}, \omega_{*}, \beta_{*}$, and $\rho_{*}$.

$H_{0}: F \varphi_{*}(\tau)=f$ versus $H_{1}: F \varphi_{*}(\tau) \neq f$

$H_{0}: S \omega_{*}(\tau)=s$ versus $H_{1}: S \omega_{*}(\tau) \neq s$

$H_{0}: S \beta_{*}(\tau)=s$ versus $H_{1}: S \beta_{*}(\tau) \neq s$

$H_{0}: S \rho_{*}(\tau)=s$ versus $H_{1}: S \rho_{*}(\tau) \neq s$

In the null and alternate hypothesis, $\mathrm{F}$ and $\mathrm{f}$ are the $h^{*} p s$, and $h^{*} 1$ denote the specified metrics, while $\mathrm{S}$ and $\mathrm{s}$ are the $h^{*} s$, and $h^{*} 1$ are the pre-specified matrices in which $h$ denotes for some restrictions (Cho et al. 2015) and $i$ denotes for economic growth (Y), energy production (E), and corruption (C), respectively. This paper tests the four null hypotheses for each parameter $\rho_{*}$; i.e., $H_{0}: \rho_{*}(0.05)=\rho_{*}(0.10)=\rho_{*}(0.20)=$. ........... $=\rho_{*}(0.90)=\rho_{*}(0.95)$ against the alternative $H_{1}: \rho_{*}(0.05) \neq \rho_{*}(0.10) \neq \rho_{*}(0.20) \neq$. $\ldots \ldots \ldots \ldots \neq \rho_{*}(0.90) \neq \rho_{*}(0.95)$. A similar method is carried out for the null and alternative hypotheses of Y, E, C, and four cumulative short-run parameters $\varphi_{*}, \omega_{*}, \lambda_{*}$, and $\theta_{*}$. A similar method is applied to test the short- and long-run integrating parameters to explore the nonlinear trend when we take energy production and economic growth as dependent variables (Model 2 and Model 3).

\section{Data and variable description}

This paper chooses Pakistan as a study area that is the most affected and vibrant nation on the globe. Human development, energy production, and corruption situation in Pakistan are very vulnerable. The data for this study is taken from the World Bank, BP statistical review, and Transparency International from 1960 to 2016. The data on human development is taken from the Human Development Report, which is measured as a proxy of Human Development Index (HDI) (World Bank 2016) from 1990 to 2016, while we calculate the Human Development Index as $H D I=\sqrt[3]{L E I \times E I \times I I}$ from 1960 to 1990 . The data of income inequality, education (primary, secondary, university), life expectancy rate, and economic growth (GDP) are taken from the CD Room of world development indicator of World Bank. The data of energy production that is measured by total electricity generation (TWh) is taken from BP statistical review (BP 2017) ${ }^{1}$. The data of corruption that is measured as the proxy for Corruption Perception Index is taken from Transparency International from 1995 to 2016, while a similar survey and method are carried out to calculate the Corruption Perception Index for Pakistan from 1960 to 1994. The details of all the variables and their summary, definition, and data sources are shown in Table 1.

\section{Results and discussion}

We report the descriptive statistics of human development, energy production, corruption, and economic growth in Table 2. The descriptive statistic indicates that the mean average of human development is less and contributing negatively as compared to energy production, corruption, and economic growth. The data on energy production, corruption, and economic growth follows a high variation as compared to human development. The data on human development, energy production, and economic growth is negatively skewed, while the data on corruption is positively skewed. It means that human development, energy production, and economic growth have a long right tail than the normal distribution, while corruption has a fatter tail than a normal distribution. At last, Jarque-Bera test statistics also confirm that the data on human development, energy production, corruption, and economic growth is normally distributed.

We apply the Augmented Dicky Fuller (ADF) test of Dickey and Fuller (1979); Phillips-Perron (PP) test of Phillips and Perron (1988); Kwiatkowski (KPSS) test of Kwiatkowski et al. (1992); and unit root tests to check the stationarity of the selected variables. The results confirm that all the variables are stationary at the first difference I(1) at $1 \%$ and $5 \%$ level of significance (Table 3 ). These results indicate that the QARDL model is an appropriate model for this research.

\section{QARDL model results}

When we take human development as a dependent variable, the estimated results by the OLS method confirm the linear cointegration relationship between human development, energy production, economic growth, and corruption. The speed of adjustment coefficient is also significant with a positive sign for the case of Pakistan. For the long-run relationship, the linear long-run cointegration parameters between

\footnotetext{
${ }^{1}$ The further details can be found in Huang (2016).
} 
Table 1 Variable description and data sources

\begin{tabular}{|c|c|c|c|}
\hline Variable name & Symbol & Description & Source \\
\hline Energy production & $\mathrm{E}$ & $\begin{array}{l}\text { The energy production includes } \\
\text { total electricity generation } \\
\text { based on gross output in } \\
\text { terawatt-hours (TWh) }\end{array}$ & (BP 2017) \\
\hline Economic growth & $\mathrm{Y}$ & $\begin{array}{l}\text { Economic growth is measured } \\
\text { in } \\
\text { US dollar per capita } \\
\text { (constant 2010 US Dollar) }\end{array}$ & World Bank \\
\hline Corruption & $\mathrm{C}$ & Index & $\begin{array}{l}\text { Transparency International and } \\
\text { authors own calculation }\end{array}$ \\
\hline Human Development Index & $\mathrm{H}$ & Index & $\begin{array}{l}\text { World Bank (2016) and authors } \\
\text { own calculation }\end{array}$ \\
\hline
\end{tabular}

economic growth and corruption are found insignificant, which means that human development cannot influence economic growth and corruption in the long run, while energy production is significantly linked to human development in the case of Pakistan (see Table 4).

The estimated results of QARDL model are reported in Table 4 when we take human development as a dependent variable for the case of Pakistan. The parameter $\rho_{*}$ is found positively significant in all quantiles which indicates that there is an aversion in the long-run equilibrium between human development, economic growth, energy production, and corruption in all eleven quantiles. The findings also prove that $\beta_{E}$ is significant in some quantiles, which shows a long-term upward trend in energy production and human development. The possible economic reason for this finding is that recently Pakistan is facing the worst energy crises, which are affecting the whole growth process of the economy, and it is also affecting the human development process in the country. It is worth mentioning here that the long-run cointegration

Table 2 Descriptive statistics

\begin{tabular}{lllll}
\hline & $\mathrm{H}$ & $\mathrm{E}$ & $\mathrm{C}$ & $\mathrm{Y}$ \\
\hline Mean & -0.390 & 1.618 & 1.289 & 2.846 \\
Median & -0.388 & 1.681 & 1.275 & 2.874 \\
Maximum & -0.202 & 2.062 & 1.477 & 3.071 \\
Minimum & -0.580 & 0.960 & 1.146 & 2.585 \\
Std. Dev. & 0.101 & 0.337 & 0.098 & 0.143 \\
Skewness & -0.257 & -0.525 & 0.275 & -0.221 \\
Kurtosis & 1.963 & 2.079 & 1.744 & 1.795 \\
Jarque-Bera & 2.900 & 4.231 & 4.074 & 3.570 \\
Probability & 0.234 & 0.120 & 0.130 & 0.167 \\
Sum & -20.286 & 84.171 & 67.078 & 148.031 \\
Sum Sq. Dev. & 0.522 & 5.796 & 0.493 & 1.043 \\
Observations & 52 & 52 & 52 & 52 \\
\hline
\end{tabular}

Note: H, E, C, and Y denote human development, energy production, corruption, and economic growth, respectively. Source: Output of STATA software version 14 parameter of energy production is positively significant, which indicates an upward trend in human development and energy production. This result is consistent with the findings of Ouedraogo (2013b) and Wang et al. (2018), who found a positive association between energy and human development. In the case of Pakistan, our results are not in line with Wang et al. (2018), who argued that there is a NIL association between energy and human development. Regarding the association between human development and economic growth, the findings also show that $\beta_{Y}$ is also negatively significant in most of the quantiles that prove a long-term downward trend in economic growth and human development. Indeed, human development drives the economic process of any country. However, the possible economic reasoning in the case of Pakistan is that the situation of human development is vulnerable, and due to this reason, it is negatively affecting the growth process of the country as indicated by the findings of this paper. Therefore, the result of this paper is not in line with Blume and Voigt (2007) and Sultan and Waheed (2014), who found a positive link between human development and economic growth. When we look at the linkage of human development and corruption, results confirm a negative association in the first quantiles. It means that energy production, economic growth, and corruption are the leading indicators, which are affecting the human development process in the country. The long-run positive and negative associations of

Table 3 Unit root test results

\begin{tabular}{|c|c|c|c|c|c|c|}
\hline \multirow[t]{2}{*}{ Variable } & \multicolumn{3}{|l|}{ Level } & \multicolumn{3}{|c|}{ 1st difference } \\
\hline & $\mathrm{ADF}$ & $\mathrm{PP}$ & KPSS & $\mathrm{ADF}$ & PP & KPSS \\
\hline $\mathrm{H}$ & -2.58 & -3.04 & $0.51^{*}$ & $-4.05 * *$ & $-7.70 *$ & 0.03 \\
\hline $\mathrm{E}$ & -1.87 & -1.59 & $0.95^{*}$ & $-5.86^{*}$ & $-6.98^{*}$ & 0.02 \\
\hline Y & -2.01 & -1.92 & $0.74^{*}$ & $-4.35^{*}$ & $-6.25^{*}$ & 0.05 \\
\hline $\mathrm{C}$ & -2.80 & -2.57 & $0.28^{*}$ & $-5.75^{*}$ & $-6.43^{*}$ & 0.04 \\
\hline
\end{tabular}

Note: $*$ and $* *$ confirm the rejection of the null against the unit root between all the variables at $1 \%$ and $5 \%$ level of significance, respectively. Source: Output of STATA software version 14 
energy production, economic growth, and corruption to the human development in the country corroborate the idea that effective and efficient policy tools are required to support the energy production process that can enhance the growth and human development process in the country. Therefore, the Pakistani government and policymakers must take some practical measures to enhance and sustain the development process of the country. For the short-run dynamics, when we take human development as a dependent variable, our results are insignificant for energy production, economic growth, and corruption in the case of Pakistan. It means that this phenomenon is not a short-run growth dilemma.

When we take energy production as a dependent variable, the estimated results by the OLS method confirm the linear cointegration relationship between economic growth and corruption. The speed of the adjustment coefficient is found insignificant in the case of Pakistan. For the long-run relationship, the linear long-run cointegration parameters between economic growth and corruption are found significant which means that energy production can influence economic growth and corruption in the long run (see Table 5).

The estimated results of QARDL model (Model 2) are reported in Table 5 when we take energy production as a dependent variable for the case of Pakistan. The parameter $\rho_{*}$ is found negatively significant in upper quantiles, which indicates that there is a reversion in the long-run equilibrium between human development, economic growth, energy production, and corruption in upper quantiles. The findings also proved that $\beta_{Y}$ is highly significant in upper high quantiles, which shows a long-term upward trend in energy production and economic growth. The possible economic reason for this finding is that recently Pakistan is facing the worst energy crises, which are worse affecting the whole growth process of the economy. It is worth mentioning here that the long-run cointegration parameter of economic growth is positively significant, which indicates an upward trend in economic growth and energy production. Our results are consistent with the findings of Apergis and Payne (2009), Aslan et al. (2014), Ouedraogo (2013a), and Ozturk et al. (2010), who supported the growth hypothesis. Regarding the association between human development, corruption, and energy production, our findings found NIL association, which indicates that human development and corruption cannot affect the production process of energy in the country. There may be some other factors like political instability, and lack of energy resource management is an essential indicator that must take into account the energy production process. The long-run positive association of energy economic growth to energy production in the country corroborates the idea that effective and efficient policy tools are required to support the energy production process that can enhance the growth and energy development process in the country. Therefore, the Pakistani government and policymakers must take some practical measures to enhance 
and sustain the development process of the country. For the short-run dynamics, when we take energy production as a dependent variable, our results are insignificant for economic growth, human development, and corruption in the case of Pakistan. It means that this phenomenon is not a short-run growth dilemma.

When we take economic growth $(\mathrm{Y})$ as a dependent variable, the estimated results by the OLS method confirm the linear cointegration relationship between energy production (E), corruption (C), and economic growth. The speed of adjustment coefficient is found significant for the case of Pakistan. For the long-run relationship, the linear long-run cointegration parameters between energy production and corruption were found significant, which means that energy production and corruption can influence economic growth in the long run (see Table 6).

The estimated results of QARDL model (Model 3) are reported in Table 6 when we take economic growth as a dependent variable for the case of Pakistan. The estimated parameter $\rho_{*}$ is found significant with the positive signs in all quantiles, which indicates that there is an aversion in the longrun equilibrium between economic growth, human development, energy production, and corruption in all quantiles during the empirical estimation. The findings also proved that $\beta_{E}$ is highly significant in all quantiles, which shows a long-term downward trend in energy production and economic growth. The possible economic reason for this finding is that recently, Pakistan is facing the worst energy crises, which are worse affecting the whole growth process of the economy. It is worth mentioning here that the long-run cointegration parameter of economic growth is positively significant which indicates a downward trend in energy production and economic growth. Our results are consistent with the findings of Apergis and Payne (2009), Aslan et al. (2014), Ouedraogo (2013a), and Ozturk et al. (2010), who supported the growth hypothesis. It means that energy production is the leading indicator, which is affecting the growth process in the country. The long-run negative association of economic growth to energy production in the country corroborates the idea that effective and efficient policy tools are required to support the energy production process that can enhance the growth and energy development process in the country. Therefore, the Pakistani government and policymakers must take some practical measures to enhance and sustain the development process of the country. Regarding the association between corruption and economic growth, results confirm the significance with a positive sign that indicates the positive association between corruption and economic growth. It means that an increase in economic growth leads to increased corruption. Our results are not in line with Mo (2001), who found a negative association between corruption and economic growth. The possible economic reason for this finding is that Pakistan's economy is at the stage of the brink where more than one factor is 
affecting the growth process of the country. However, our results are more journalistic. Corruption is most prevalent where other factors like inefficient institutional systems such as weak judicial and legislative system are the most dominant factor. For the short-run dynamics, when we take economic growth as a dependent variable, our results are significant for energy production in the case of Pakistan. It means that this phenomenon is a short-run growth dilemma. Our results also support the energy-growth hypothesis in the short run as well.

Figures 3, 4, and 5 corroborate the dynamic behavior of the parameters that are estimated overall quantiles understudy for Pakistan, respectively. According to these figures, the estimated parameters show dissimilarities with linear estimations, which indicate that parameters behave differently in all quantiles. It is also shown in Figures 3, 4, and 5 that the dynamic parameters of $\beta_{i}(\tau)$ indicate the potential difference of cointegration. Further, we notice that $\beta_{i}$ high are negative instead of insignificant values which shows a long-run relationship. Similarly, $\beta_{i}$ low show that the current cointegration remains same in our scenario.

The corresponding Wald test results are reported in Table 7 that shows the null of linearity on the speed of adjustment parameters are rejected against the alternate when we take human development and economic growth as dependent variables (Model 1 and Model 3), while the null of linearity on the speed of adjustment parameters is accepted against the alternate when we take energy production as the dependent variable (Model 2) for the Pakistan economy. However, the null of the parameters shows the consistency in all the quantiles, which indicate the long-run dynamics among the associated variables. The integrating parameters of energy production $\left(\beta_{E}\right)$, economic growth $\left(\beta_{Y}\right)$, and corruption $\left(\beta_{C}\right)$ reject the null hypothesis when we take human development (Model 1) as a dependent variable. When we take energy production as a dependent variable (Model 2), the integrating parameter of corruption $\left(\beta_{C}\right)$ rejects the null hypothesis that confirms a long-run relationship between energy production and corruption. Similarly, the integrating parameters of human development $\left(\beta_{H}\right)$ reject the null hypothesis that confirms a long-run relationship between human development and economic growth when we take economic growth as a dependent variable (Model 3). It means that the integrating parameters of human development, energy production, economic growth, and corruption have a long-run dynamic relationship with human development, energy production, and economic growth during the pattern of different quantiles for Pakistan. This kind of results may have a reason for the fact that Pakistan is passing through severe energy crises, vulnerable human development indexes, and corruption perception index that have an enormous impact on the economic growth of Pakistan. This long-run integrating association between energy production, human development, corruption, and economic growth urges the policymakers to take adequate measures for sustainable development. 

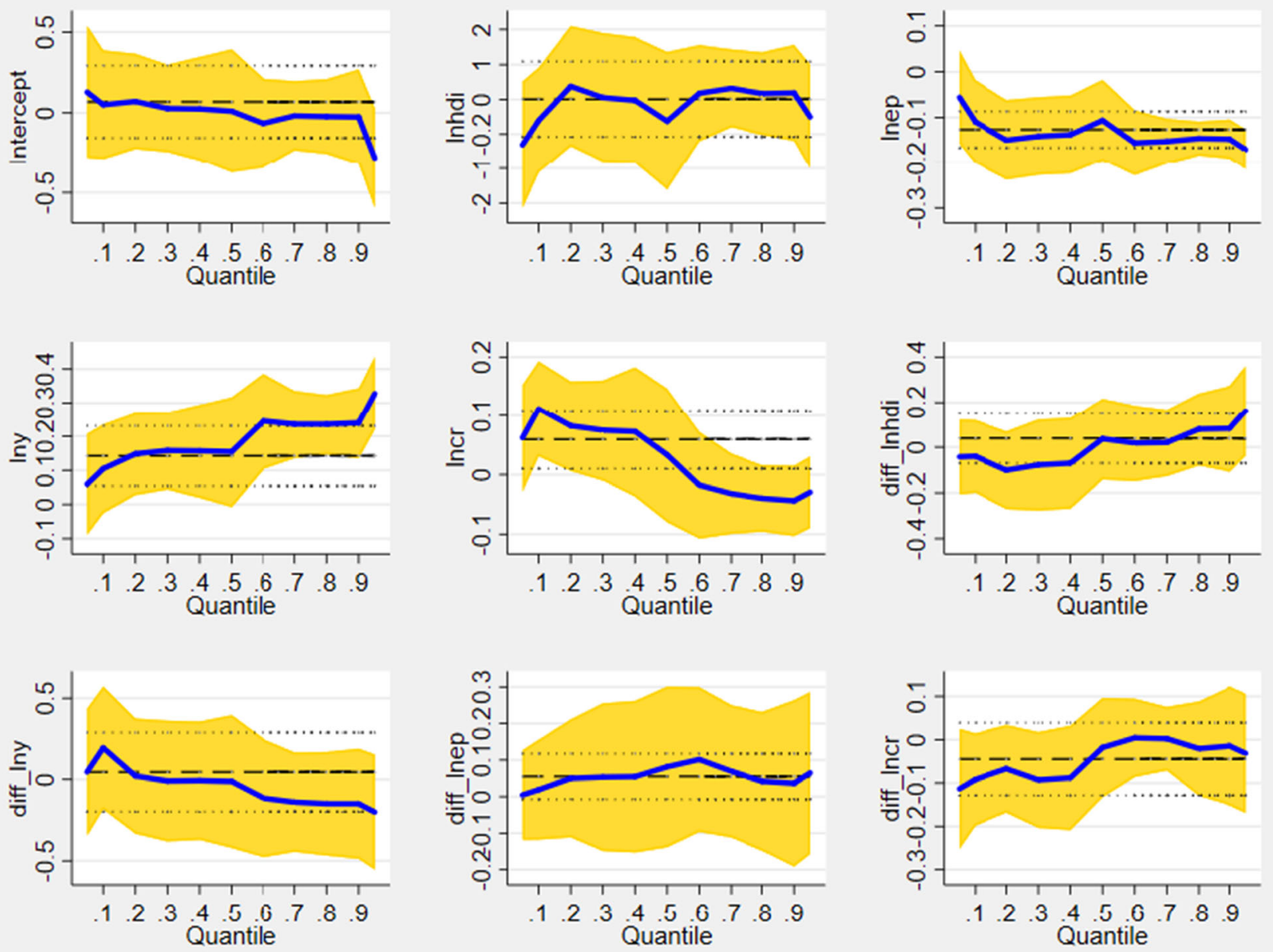

Fig. 3 Quantile parameter estimates (Model 1). Note: the plot shows the estimated parameter (blue solid line) on the vertical axis for all the quantiles with 95\% confidence interval (outer shaded area). Source: Authors own calculations based on the data using STATA software version 14

For the short-run dynamics, the estimated cumulative impacts of previous levels of human development (Model 1), energy production (Model 2), and economic growth (Model 3) are reported in Table 7 and indicate that the Wald test strongly rejects the null hypothesis for the parameters of human development, energy production, and economic growth for all quantiles under investigation. The Wald test rejects the null hypothesis and confirms the short-run impact of human development on economic growth, energy production, and corruption in all quantiles (Model 1). The results also indicate that economic growth, energy production, and corruption have an asymmetric impact on human development in the case of Pakistan. Similarly, the Wald test rejects the null hypothesis and confirms the short-run impact of energy production on economic growth and corruption (Model 2). It means that economic growth and corruption have an asymmetric impact on energy production in the country. When we take economic growth as a dependent variable (Model 3), the Wald test rejects the null hypothesis and confirms a short-run impact of economic growth on human development, energy production, and corruption for all quantiles for the case of Pakistan. Results also indicate that human development, energy production, and corruption have an asymmetric impact on the economic growth of Pakistan.

\section{Conclusion and policy suggestion}

This paper introduced a sustainable development path for the Pakistan economy by incorporating human development and energy production and economic growth with corruption into the model. The Quantile Autoregressive Distributed Lag (QARDL) model is carried out to quantify the short- and long-run association between the selected variables and covered the period of 1965-2016. The model confirmed the appropriateness of this study due to the existence of short- and 

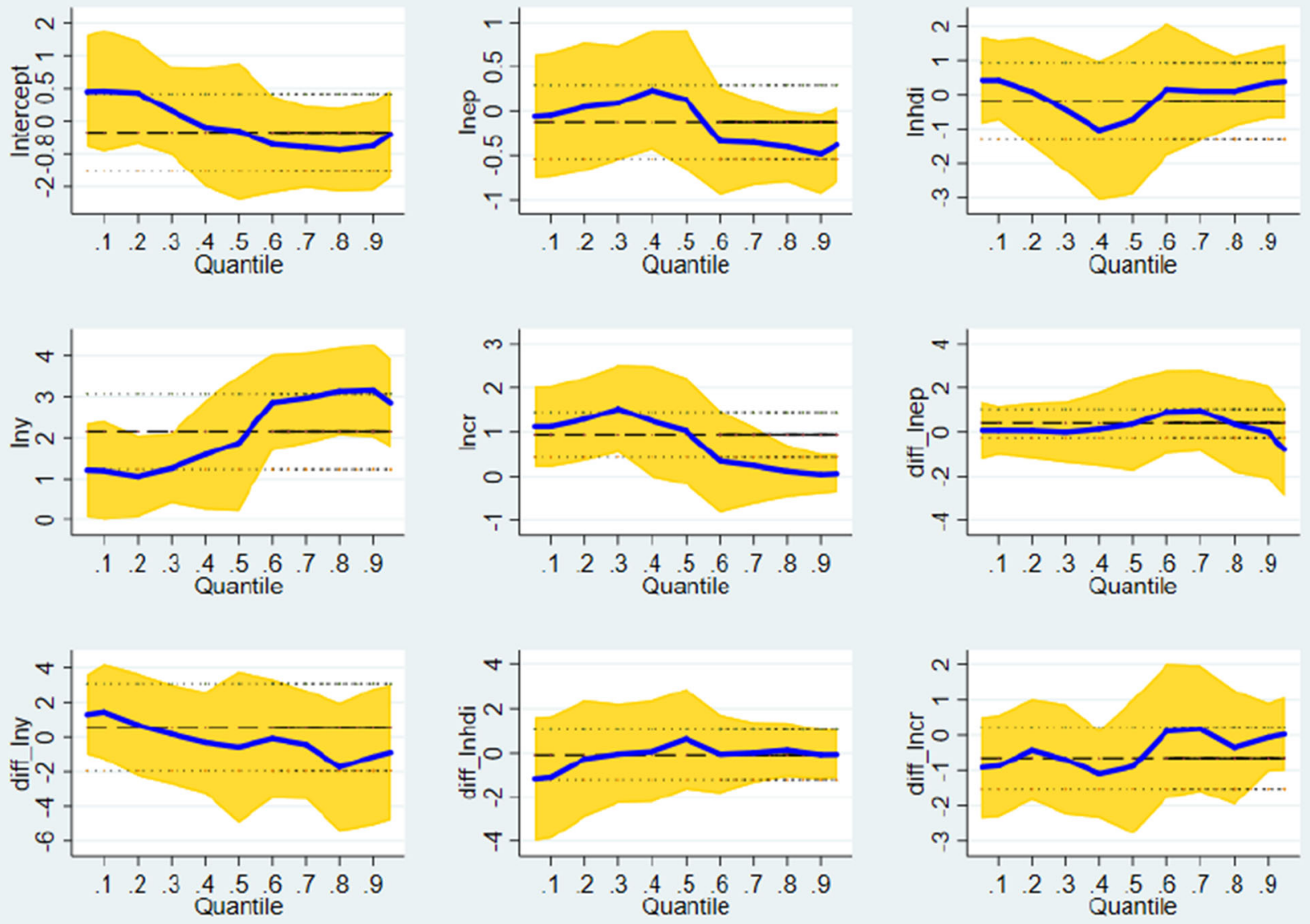

Fig. 4 Quantile parameter estimates (Model2). Note: the plot shows the estimated parameter (blue solid line) on the vertical axis for all the quantiles with a 95\% confidence interval (outer shaded area). Source: Authors own calculations based on the data using STATA software version 14

long-run dynamic impacts between the dependent and independent variables. The asymmetric cointegration for shortand long-term association is also checked by applying the Wald test statistic. The findings of this paper suggested some evidence for policymakers to find a sustainable development path for the country.

The empirical results showed a linear cointegration relationship between human development, energy production, economic growth, and corruption by a simple OLS method as well as the QARDL model within some quantiles in the country. Results confirmed a positive association between energy production and human development, while economic growth negatively contributed to human development in the case of Pakistan. Similarly, economic growth had a positive impact on energy production, while energy production negatively contributed to the economic growth of Pakistan. Results also confirmed that corruption had a positive impact on economic growth. These results are in line with the literature. Additionally, the findings of this research are unable to support the view that corruption can impede the growth process of Pakistan. However, this research is also unable to support the view that human development has a positive impact on economic growth, while the findings supported the growth hypothesis in the case of energy-growth relation. In the particular case of Pakistan, the research findings derived new innovative ideas for sustainable development that could be adopted by the policymakers and the Pakistani government to enhance the development process of the country.

Especially, from the policy perspective, the findings corroborate the idea that effective and efficient policy tools are required to culminate the issues of energy production, human development, and corruption to enhance the growth and energy development process in the country to ensure a sustainable development process. Therefore, results ensured that a policy is required that can enhance the energy production process in the country and can enhance human development which can in return promote the sustainable development path and can enhance the growth process of the country in the long run. 

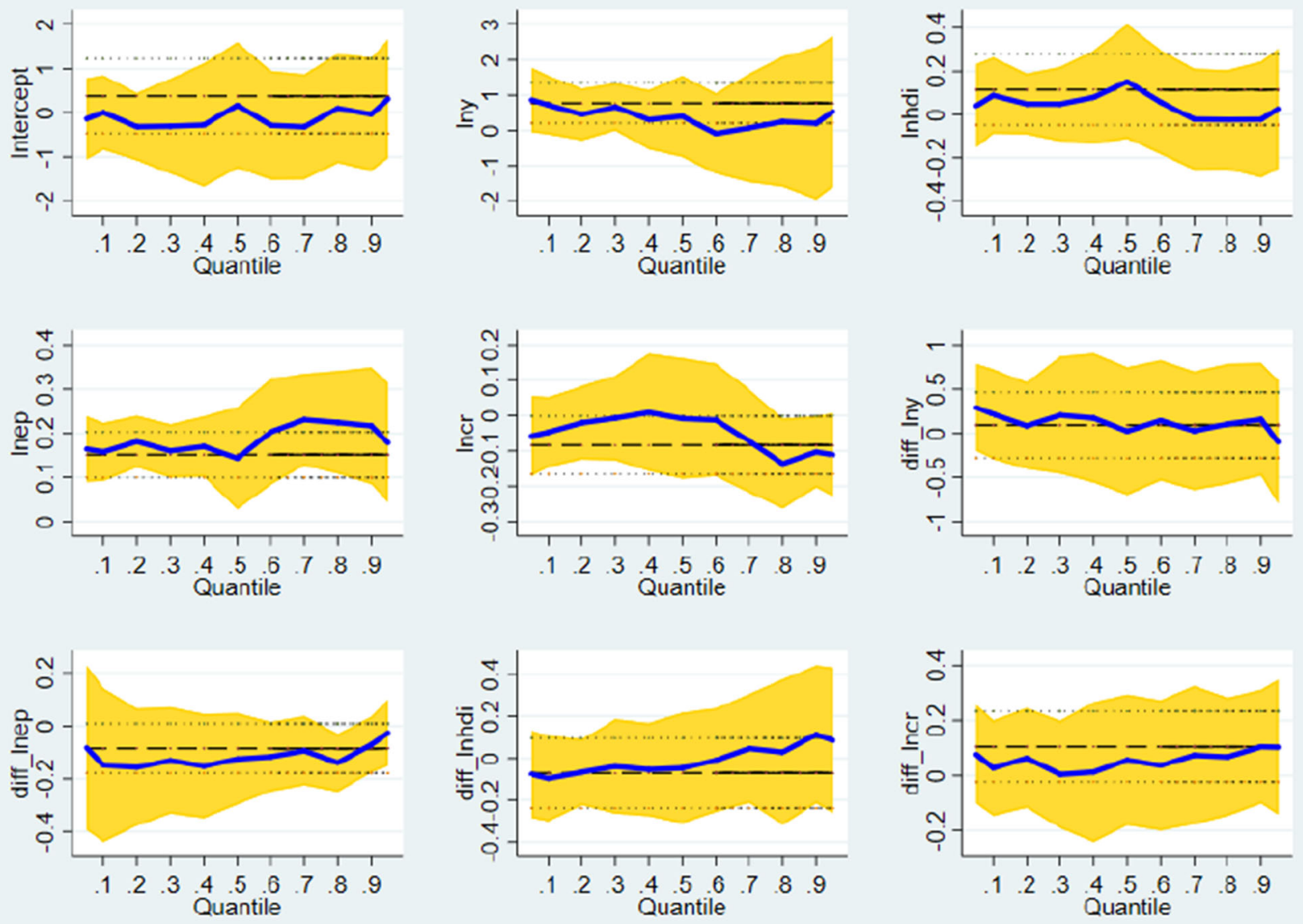

Fig.5 Quantile parameter estimates (Model 3). Note: the plot shows the estimated parameter (blue solid line) on the vertical axis for all the quantiles with a 95\% confidence interval (outer shaded area). Source: Authors own calculations based on the data using STATA software version 14

Pakistani government can achieve its millennium development goals to culminate poverty and hunger and enhance the

Table 7 Wald test results

\begin{tabular}{llll}
\hline & Model 1 & Model 2 & Model 3 \\
\hline$\rho_{*}$ & $6.72 *[0.00]$ & $0.72[0.70]$ & $3.83^{*}[0.00]$ \\
$\beta_{H}$ & --- & $1.49[0.99]$ & $32.89 *[0.00]$ \\
$\beta_{E}$ & $35.82 *[0.00]$ & ------ & $11.56[0.31]$ \\
$\beta_{Y}$ & $20.93 *[0.02]$ & $13.83[0.18]$ & ---- \\
$\beta_{C}$ & $82.37 *[0.00]$ & $27.13 *[0.00]$ & $9.42[0.49]$ \\
$\varphi_{1}$ & $5.77 *[0.00]$ & $1.38[0.22]$ & $5.27 *[0.00]$ \\
$\omega_{1}$ & $2.16^{* * *[0.04]}$ & $1.06[0.41]$ & $1.47[0.18]$ \\
$\lambda_{1}$ & $1.53[0.16]$ & $0.68[0.73]$ & $4.97 *[0.00]$ \\
$\theta_{1}$ & $1.48[0.18]$ & $2.01 * * *[0.05]$ & $5.05^{*}[0.00]$ \\
Cumulative short-run effects & & \\
$\varphi_{*}$ & $19.98^{* *}[0.02]$ & $3.92[0.95]$ & $22.04 *[0.01]$ \\
$\lambda_{*}$ & $31.45 *[0.00]$ & $23.07 *[0.01]$ & $46.71 *[0.00]$ \\
$\theta_{*}$ & $25.10^{*}[0.00]$ & $19.79 * *[0.03]$ & $16.72^{* * *}[0.08]$ \\
\hline
\end{tabular}

Note: The P-value is reported in parenthesis [], and *, **, and *** denote the $1 \%, 5 \%$, and $10 \%$ level of significance. Source: Authors own calculations based on the data using STATA software version 14 energy production process by the sustainable development process by resolving the issues of human development, energy production, and corruption. Achieving this goal, the Pakistani government should integrate new innovative policies with new energy technologies that can culminate in the unemployment rate of the country that can, in turn, promote the Human Development Index of the country. Being a developing country, the Pakistan economy cannot install a massive project of energy production, and the energy production of coal, oil, and gas hurt the health of the population. Therefore, we urge the Pakistani government and policymakers to introduce nuclear and renewable energy production that is cheaper than nonrenewable energy production. By doing so, the northern areas of Pakistan are best located for wind and water energy, while the southern areas of the country are the best-suited location for solar energy production. At the same time, the revised tax policy forms are needed to attract foreigners and local investors to invest in new energy production reforms. The productive means of energy production may lower the Human Development Index in the country by improving the living 
standard and economic empowerment of the peoples. In this way, corruption will be controlled in the country. It will contribute to achieving the millennium development goals. Additionally, authorities should deal with environmental regulations that can enhance energy efficiency and growth level. The country is in the growing stage; any change in income level can change energy usage that can change pollution level significantly. Pakistan can reduce corruption through the compliance of Federal Accountability Bureau (FBR). Anticorruption programs must give importance to pubic regulations.

Availability of data and materials All data used in this study are available upon request. The information on the sources of data is written in this paper.

Author contribution Muhammad Luqman: methodology, data collection, conceptualization, and writing - original draft preparation. Yafei Li: writing - reviewing and editing. Salah Ud-Din Khan: software and validation. Najid Ahmad: reviewing, editing, and supervision.

\section{Declarations}

Ethics approval and consent to participate Not applicable.

Consent for publication Not applicable.

Competing interests The authors declare no competing interests.

\section{References}

Acaravci A, Erdogan S, Akalin G (2015) The electricity consumption, real income, trade openness and foreign direct investment: the empirical evidence from Turkey. Int J Energy Econ Policy 5:1050 1057

Acemoglu D, Verdier T (1998) Property rights, corruption and the allocation of talent: a general equilibrium approach. Econ J 108:13811403. https://doi.org/10.1111/1468-0297.00347

Ahmad N, Du L (2017) Effects of energy production and $\mathrm{CO}_{2}$ emissions on economic growth in Iran: ARDL approach. Energy 123:521537. https://doi.org/10.1016/j.energy.2017.01.144

Ahmad E, Ullah MA, Arfeen MI (2012) Does corruption affect economic growth? Lat Am J Econ 49:277-305

Ahsan H, Haque ME (2017) Threshold effects of human capital: schooling and economic growth. Econ Lett 156:48-52. https://doi.org/10. 1016/j.econlet.2017.04.014

Apergis N, Payne JE (2009) Energy consumption and economic growth: evidence from the Commonwealth of Independent States. Energy Econ 31:641-647. https://doi.org/10.1016/j.eneco.2009.01.011

Aslan A, Apergis N, Yildirim S (2014) Causality between energy consumption and GDP in the U.S.: evidence from wavelet analysis. Front Energy 8:1-8. https://doi.org/10.1007/s11708-013-0290-6

Bayley DH (1966) The effects of corruption in a developing nation. Polit Res Q 19:719-732. https://doi.org/10.1177/106591296601900410

Blume L, Voigt S (2007) The economic effects of human rights. Kyklos 60:509-538. https://doi.org/10.1111/j.1467-6435.2007.00383.x

BP (2017) Statistical review of world energy. https://www.bp.com/en/ global/corporate/energy-economics/statistical-review-of-worldenergy.html
Chiou-Wei SZ, Chen C-F, Zhu Z (2008) Economic growth and energy consumption revisited - evidence from linear and nonlinear Granger causality. Energy Econ 30:3063-3076. https://doi.org/10. 1016/J.ENECO.2008.02.002

Cho JS, Kim T, Shin Y (2015) Quantile cointegration in the autoregressive distributed-lag modeling framework. J Econ 188: 281-300

Corruption Perception Index (2021) In: https://www.transparency.org/en/ cpi/2020/index/nzl

Costantini V, Monni S (2008) Environment, human development and economic growth. Ecol Econ 64:867-880. https://doi.org/10.1016/ j.ecolecon.2007.05.011

d'Agostino G, Dunne JP, Pieroni L (2012) Corruption, military spending and growth. Def Peace Econ 23:591-604. https://doi.org/10.1080/ 10242694.2012.663579

Del Monte A, Papagni E (2001) Public expenditure, corruption, and economic growth: the case of Italy. Eur J Polit Econ 17:1-16. https:// doi.org/10.1016/S0176-2680(00)00025-2

Dickey DA, Fuller WA (1979) Distribution of the estimators for autoregressive time series with a unit root. J Am Stat Assoc 74: 427. https://doi.org/10.2307/2286348

Dogan E (2014) Energy consumption and economic growth: evidence from low-income countries in Sub-Saharan Africa. Int J Energy Econ Policy 4:154-162

Dogan E (2015) Revisiting the relationship between natural gas consumption and economic growth in Turkey. Energy Sources, Part B Econ Planning, Policy 10:361-370. https://doi.org/10.1080/ 15567249.2014.931486

Dogan E, Sebri M, Turkekul B (2016) Exploring the relationship between agricultural electricity consumption and output: new evidence from Turkish regional data. Energy Policy 95:370-377. https://doi.org/ 10.1016/j.enpol.2016.05.018

Dridi M (2013) Corruption and economic growth: the transmission channels. J Bus Stud Q 4:121-152

Fang Z, Chang Y (2016) Energy, human capital and economic growth in Asia Pacific countries - evidence from a panel cointegration and causality analysis. Energy Econ 56:177-184. https://doi.org/10. 1016/j.eneco.2016.03.020

Ferrannini A, Barbieri E, Biggeri M, Di Tommaso MR (2021) Industrial policy for sustainable human development in the post-Covid19 era. World Dev 137:105215. https://doi.org/10.1016/j.worlddev.2020. 105215

Fredriksson PG, Vollebergh HRJ, Dijkgraaf E (2004) Corruption and energy efficiency in OECD countries: theory and evidence. J Environ Econ Manag 47:207-231. https://doi.org/10.1016/j.jeem. 2003.08.001

Furuoka F (2016) Natural gas consumption and economic development in China and Japan: an empirical examination of the Asian context. Renew Sust Energ Rev 56:100-115. https://doi.org/10.1016/j.rser. 2015.11.038

Gani A (2021) Sustainability of energy assets and corruption in the developing countries. Sustain Prod Consum 26:741-751. https://doi. org/10.1016/j.spc.2020.12.023

Gründler K, Potrafke N (2019) Corruption and economic growth: new empirical evidence. Eur J Polit Econ 60:101810. https://doi.org/10. 1016/j.ejpoleco.2019.08.001

Gyimah-Brempong K (2002) Corruption, economic growth, and income inequality in Africa. Econ Gov 3:183-209. https://doi.org/10.1007/ s101010200045

Gyimah-Brempong K, de Gyimah-Brempong SM (2006) Corruption, growth, and income distribution: are there regional differences? Econ Gov 7:245-269. https://doi.org/10.1007/s10101-005-0008-2

Hafner KA, Mayer-Foulkes D (2013) Fertility, economic growth, and human development causal determinants of the developed lifestyle. J Macroecon 38:107-120. https://doi.org/10.1016/j.jmacro.2013.04. 001 
Helene PW (1998) Economic security, private investment, and growth in developing countries

Huang CJ (2016) Is corruption bad for economic growth? Evidence from Asia-Pacific countries. North Am J Econ Financ 35:247-256. https://doi.org/10.1016/j.najef.2015.10.013

Huntington SP (1970) Political order in changing societies. VRÜ Verfassung und $\mathrm{R}$ Übersee 3:257-261

Ishola Mobolaji H, Omoteso K (2009) Corruption and economic growth in some selected transitional economies. Soc Responsib J 5:70-82. https://doi.org/10.1108/17471110910940014

Johnson ND, LaFountain CL, Yamarik S (2011) Corruption is bad for growth (even in the United States). Public Choice 147:377-393. https://doi.org/10.1007/s11127-010-9634-5

Kahsai MS, Nondo C, Schaeffer PV, Gebremedhin TG (2012) Income level and the energy consumption-GDP nexus: evidence from SubSaharan Africa. Energy Econ 34:739-746. https://doi.org/10.1016/j. eneco.2011.06.006

Karekezi S, McDade S, Boardman B, Kimani J, Lustig N (2012) Energy, poverty, and development. In: Global Energy Assessment Writing Team (ed) Global Energy Assessment: Toward a Sustainable Future. Cambridge University Press, Cambridge, pp 151-190

Khan MK, Teng J-Z, Khan MI (2019) Effect of energy consumption and economic growth on carbon dioxide emissions in Pakistan with dynamic ARDL simulations approach. Environ Sci Pollut Res 26: 23480-23490. https://doi.org/10.1007/s11356-019-05640-x

Khodabakhshi A (2011) Relationship between GDP and Human Development Indices in India. Int J Trade Econ Financ:251-253. https://doi.org/10.7763/IJTEF.2011.V2.111

Klitgaard RE (1988) Controlling corruption. University of California Press

Kwiatkowski D, Phillips PCB, Schmidt P, Shin Y (1992) Testing the null hypothesis of stationarity against the alternative of a unit root: how sure are we that economic time series have a unit root? J Econ 54: 159-178. https://doi.org/10.1016/0304-4076(92)90104-Y

Leff NH (1964) Economic development through bureaucratic corruption. Am Behav Sci 8:8-14. https://doi.org/10.1177/ 000276426400800303

Lui FT (1985) An equilibrium queuing model of bribery. J Polit Econ 93: 760-781. https://doi.org/10.1086/261329

Maiyaki A (2010) The effects of corruption on the Nigerian economy. IBA Bus Rev 2:111-126

Mauro P (1995) Corruption and growth. Q J Econ 110:681-712

Menegaki AN, Tugcu CT (2016) Rethinking the energy-growth nexus: proposing an index of sustainable economic welfare for SubSaharan Africa. Energy Res Soc Sci 17:147-159. https://doi.org/ 10.1016/j.erss.2016.04.009

Mo PH (2001) Corruption and economic growth. J Comp Econ 29:6679. https://doi.org/10.1006/jcec.2000.1703

Mohmmed A, Li Z, Olushola Arowolo A, Su H, Deng X, Najmuddin O, Zhang Y (2019) Driving factors of CO2 emissions and nexus with economic growth, development and human health in the top ten emitting countries. Resour Conserv Recycl 148:157-169. https:// doi.org/10.1016/j.resconrec.2019.03.048

Mustafa G, Rizov M, Kernohan D (2017) Growth, human development, and trade: the Asian experience. Econ Model 61:93-101. https://doi. org/10.1016/j.econmod.2016.12.007

Nasreen S, Anwar S (2014) Causal relationship between trade openness, economic growth and energy consumption: a panel data analysis of Asian countries. Energy Policy 69:82-91. https://doi.org/10.1016/j. enpol.2014.02.009

Niu S, Jia Y, Wang W, He R, Hu L, Liu Y (2013) Electricity consumption and human development level: a comparative analysis based on panel data for 50 countries. Int J Electr Power Energy Syst 53: 338-347. https://doi.org/10.1016/j.ijepes.2013.05.024

Ouattara B (2004) Foreign aid and fiscal policy in Senegal. Mimeo University of Manchester Manchester
Ouedraogo NS (2013a) Energy consumption and human development: evidence from a panel cointegration and error correction model. Energy 63:28-41. https://doi.org/10.1016/j.energy.2013.09.067

Ouedraogo NS (2013b) Energy consumption and economic growth: evidence from the economic community of West African States (ECOWAS). Energy Econ 36:637-647. https://doi.org/10.1016/j. eneco.2012.11.011

Ozcan B, Tzeremes PG, Tzeremes NG (2020) Energy consumption, economic growth and environmental degradation in OECD countries. Econ Model 84:203-213. https://doi.org/10.1016/j.econmod.2019. 04.010

Ozturk I, Aslan A, Kalyoncu H (2010) Energy consumption and economic growth relationship: evidence from panel data for low and middle income countries. Energy Policy 38:4422-4428. https://doi.org/10. 1016/j.enpol.2010.03.071

Paksha PB (2010) Does corruption foster growth in Bangladesh? Int J Dev Issues 9:246-262. https://doi.org/10.1108/ 14468951011073325

Phillips PCB, Perron P (1988) Testing for a unit root in time series regression. Biometrika 75:335. https://doi.org/10.2307/2336182

Qureshi F, Qureshi S, Vinh Vo X, Junejo I (2021) Revisiting the nexus among foreign direct investment, corruption and growth in developing and developed markets. Borsa Istanbul Rev 21:80-91. https:// doi.org/10.1016/j.bir.2020.08.001

Ray S, Ghosh B, Bardhan S, Bhattacharyya B (2016) Studies on the impact of energy quality on human development index. Renew Energy 92:117-126. https://doi.org/10.1016/j.renene.2016.01.061

Rogers ML (2008) Directly unproductive schooling: how country characteristics affect the impact of schooling on growth. Eur Econ Rev 52:356-385. https://doi.org/10.1016/j.euroecorev.2007.03.001

Rose-Ackerman S (1999a) Corruption and government. Cambridge University Press, Cambridge

Rose-Ackerman S (1999b) Corruption and government: causes, consequences, and reform. Cambridge University Press, Cambridge

Schündeln M, Playforth J (2014) Private versus social returns to human capital: education and economic growth in India. Eur Econ Rev 66: 266-283. https://doi.org/10.1016/j.euroecorev.2013.08.011

Shahbaz M, Zeshan M, Afza T (2012) Is energy consumption effective to spur economic growth in Pakistan? New evidence from bounds test to level relationships and Granger causality tests. Econ Model 29: 2310-2319. https://doi.org/10.1016/j.econmod.2012.06.027

Shera A, Dosti B, Grabova P (2014) Corruption impact on economic growth: an empirical analysis: Discovery service for Ocean Univ of China. J Econ Dev Manag IT, Financ Mark 6:57-77

Shi Y, Pan M (2018) Dynamics of social tolerance on corruption: an economic interaction perspective. Rom J Econ Forecast 21:135-141

Shin Y, Yu B, Greenwood-Nimmo M (2014) Modelling asymmetric cointegration and dynamic multipliers in a nonlinear ARDL framework. In: Sickles RC, Horrace WC (eds) Festschrift in Honor of Peter Schmidt: Econometric Methods and Applications. Springer, New York, pp 281-314

Song C-Q, Chang C-P, Gong Q (2021) Economic growth, corruption, and financial development: global evidence. Econ Model 94:822830. https://doi.org/10.1016/j.econmod.2020.02.022

Sultan F, Waheed A (2014) Human capital and economic growth: a macroeconomic model for Pakistan. Econ Model 42:66-76. https://doi.org/10.1016/j.econmod.2014.05.021

Suri T, Boozer MA, Ranis G, Stewart F (2011) Paths to success: the relationship between human development and economic growth. World Dev 39:506-522. https://doi.org/10.1016/J.WORLDDEV. 2010.08 .020

Svensson J (2005) Eight questions about corruption. J Econ Perspect 19: $19-42$

Swaleheen M (2011) Economic growth with endogenous corruption: an empirical study. Public Choice 146:23-41. https://doi.org/10.1007/ s11127-009-9581-1 
Taiwo AO, Elumilade DO (2007) Does corruption matter for Nigeria long run growth: evidence from cointegration analyses and causality tests?

Tsaturyan S, Bryson PJ (2009) Corruption and development: the Armenian case. Int J Econ Policy inEmerging Econ 2:356. https:// doi.org/10.1504/IJEPEE.2009.030937

UNDP (2014) Human development report: sustaining human progress reducing vulnerabilities and building resilience

UNDP (2018) United Nations Development Programme. In Human Development Data (1990-2017)

Vasylieva T, Lyulyov O, Bilan Y, Streimikiene D (2019) Sustainable economic development and greenhouse gas emissions: the dynamic impact of renewable energy consumption, GDP, and corruption. Energies 12

Wang Z, Danish ZB, Wang B (2018) Renewable energy consumption, economic growth and human development index in Pakistan: evidence form simultaneous equation model. J Clean Prod 184: 1081-1090. https://doi.org/10.1016/j.jclepro.2018.02.260

Warr BS, Ayres RU (2010) Evidence of causality between the quantity and quality of energy consumption and economic growth. Energy 35:1688-1693. https://doi.org/10.1016/j.energy.2009.12.017

Wedeman A (1997) Looters, rent-scrapers, and dividend-collectors: corruption and growth in Zaire, South Korea, and the Philippines. J Dev Areas 31

World Bank (2016) Human Development Index Data of Pakistan Human Development Indicators

Xiao Z (2009) Quantile cointegrating regression. J Econ 150:248-260

Publisher's note Springer Nature remains neutral with regard to jurisdictional claims in published maps and institutional affiliations. 